\title{
Financial Derivatives in India: A Case of National Stock Exchange India
}

\author{
Sachita Yadav \\ (Research Scholar University of Rajasthan, India)
}

\begin{abstract}
Financial market is a place which provides a place for investment and helps in enhancing the income in terms of return. The main aim of financial market is to create cash flow in the market, so that individuals can take investment decision without any fear. Every investor would like to get required rate of return with minimum risk. To attain the objective of high return with minimum risk, various instruments, practices and strategies have been devised and developed in the recent past. After privatization and globalization financial market has entered into a new phase of global integration and liberalization. On the one hand integration of the Indian capital market with global market open the boundaries for investment to everyone, which also helps in increasing the cash flow, on the other hand there has increased in financial risk as the frequent changes in the interest rates, currency exchange rate and stock prices. To overcome from the increased financial risk a risk minimizing tool were launched by NSE during the year 2001, and that tool was Derivatives. This study helps in analyzing the facts behind launching of financial derivative by NSE India and how derivatives help in the growth of share market in India. The case will cover introduction, contextual note, various arguments and the results, remaining problems and new ingenuities regarding financial derivatives of NSE India.
\end{abstract}

Key Words: Financial Market, Return, Risk, Globalization, Privatization, Derivatives.

\section{Introduction To Financial Market}

Financial market is a place which provides a place for investment and helps in enhancing the income in terms of return. The main aim of financial market is to create cash flow in the market, so that individuals can take investment decision without any fear. Every investor would like to get required rate of return with minimum risk. To attain the objective of high return with minimum risk, various instruments, practices and strategies have been devised and developed in the recent past. After privatization and globalization financial market has entered into a new phase of global integration and liberalization. On the one hand integration of the Indian capital market with global market open the boundaries for investment to everyone, which also helps in increasing the cash flow, on the other hand there has increased in financial risk as the frequent changes in the interest rates, currency exchange rate and stock prices.

\section{Objectives Of The Study}

The research paper has tried to fulfill the following mentioned objectives:

- To have an information about of Indian derivative market.

- To find out the trading growth of financial derivative products in India

- To examine the global derivative trading of derivative instruments.

\subsection{Meaning \& Concepts of Financial Derivative}

\section{Introduction To Financial Derivatives}

"Literal meaning of derivative is that something which is derived. Now question arises as to what is derived? From what it is derived? Simple one line answer is that value/price is derived from any underlying asset. There is no independent value of financial derivatives and its value depends on the underlying asset. The underlying assets may be securities, commodities, bullion, currency, livestock or anything else. Derivatives encompass, firstly, the trade in financial instruments or other goods at a certain point in the future, known as forward transactions or futures, and secondly, the trade in financial instruments or other goods based on a condition to be realized at a certain future point in time, known as conditioned forward transaction or options."

\subsection{Definition of Financial Derivatives}

Section 2(ac) of Securities Contract Regulation Act (SCRA) 1956 defines Derivative as:

a) "a security derived from a debt instrument, share, loan whether secured or unsecured, risk instrument or contract for differences or any other form of security;

b) "a contract which derives its value from the prices, or index of prices, of underlying securities". 
There are two types of derivatives, commodity derivatives and financial derivatives. Firstly derivatives originated as a tool for managing risk in commodities markets in ancient time and the underlying asset is a commodity in commodity derivatives. It can be agricultural commodity or precious metals like gold, silver etc. The term financial derivative denotes a variety of financial instruments including stocks, bonds, treasury bills, interest rate, foreign currencies and other hybrid securities. Financial derivatives include futures, forwards, options, swaps, etc. Futures contracts are the most important form of derivatives, which are in existence long before the term 'derivative' was coined. Financial derivatives can also be derived from a combination of cash market instruments or other financial derivative instruments. In fact, most of the financial derivatives are not new instruments rather they are merely combinations of older generation derivatives and/or standard cash market instruments.

\subsection{Concepts of Financial Derivative}

The term 'derivatives, is an innovative financial instrument which play an important role for the development of Indian Security market. There are two important derivative instruments, which are known as future and option. The value of these instruments is derived from the value of an underlying asset. The price of derivatives is based on the price of underlying asset, like price of butter is based on price of milk. It's an instrument to minimizing the risk of price fluctuation in stock market.

By Johm c. Hull, "A very high proportion of the futures contracts that are traded do not lead to the delivery of the underlying asset. Traders usually enter into offsetting contracts to close out their position before the delivery period is reached.

\section{Evolution Of Financial Derivative}

Although, financial derivatives have been in operation since long, but they have become a major force in financial markets in the early 1970s. The basic reason behind this development was the failure of Brettonwood System and the fixed exchange rate regime was broken down. As a result, new exchange rate regime, i.e., floating rate (flexible) system based upon market forces came into existence. There is a pressure or demand and supply gap on different currencies, due to that the exchange rates were constantly changing. As a result, the business firms faced a new risk, known as currency or foreign exchange risk. Accordingly, a new financial instrument was developed to overcome this risk in the new financial environment.

Another important reason for the instability in the financial market was fluctuation in the short-term interests. This was mainly due to that most of the government at that time tried to manage foreign exchange fluctuations through short-term interest rates and by maintaining money supply targets, but which were contrary to each other. Further, the increased instability of short-term interest rates created adverse impact on long-term interest rates, and hence, instability in bond prices, because they are largely determined by long-term interest rates. The result is that it created another risk, named interest rate risk, for both the issuers and the investors of debt instruments.

Interest rate fluctuations had not only created instability in bond prices, but also in other long-term assets such as, company stocks and shares. Share prices are determined on the basis of expected present values of future dividend payments discounted at the appropriate discount rate. Discount rates are usually based on long-term interest rates in the market. So, increased instability in the long-term interest rates caused enhanced fluctuations in the share prices in the stock markets. Further volatility in stock prices is reflected in the volatility in stock market indices which causes systematic risk or market risk.

In the early 1970s, it is witnessed that the financial markets were highly instable; as a result, so many financial derivatives have been emerged as the means to manage the different types of risks stated above, and also for taking advantage of it. Hence, the first financial futures market was the International Monetary Market, established in 1972 by the Chicago Mercantile Exchange which was followed by the London International Financial Futures Exchange in 1982. A forward/future contract in commodities is regulated by, Forwards Contracts (Regulation) Act, 1952, in all over India. As per this the Forward Markets Commission (FMC) continues to have jurisdiction over commodity forward/futures contracts. The derivative trading was introduced in 2001 in India, under the Securities Contracts (Regulation) Act, 1956 (SCRA). Consequently, regulation of derivatives came under the preview of Securities Exchange Board of India (SEBI). There are separate regulatory authorities to regulate commodity and security market in India, which helps in smooth running of derivative trading.

\section{Functions of Financial Derivative}

Financial derivatives play an important role for the growth of share market. The following functions are performed by derivative market, which helps in developing of share market:

Discovery of price: There is always fear in the mind of investor regarding fluctuation in the share prices. As the financial derivative instruments are contract for future and to calculate the future price there is a requirement of 
continuous watch about the information from around the world. It also requires a high degree of transparency. The price of derivatives based on the flow of information. On the one side these information helps in finding out the price of current market and on the other side the price of current market will influence the future market, which helps in determining future price as well as current price.

Risk transfer: The derivatives market helps to transfer risks from those who have them but may not like them to those who have an appetite for them. There are various traders in financial derivative market like hedgers, speculators and arbitragers.

Link to cash markets: Cash market provides a base to derivative markets. As the value of derivatives is derived from the underlying assets, and the underlying assets are existed in cash market, so there is a link in both.

Check on speculation: Financial derivatives are exchange traded contracts which traded in a controlled environment. Due to that it transfers the speculation in a regulated market.A regulated and controlled security market helps in managing, monitoring, and surveillance of the trading activities of speculators, which helps investors to control over share price fluctuations.

Increases savings and investments: A financial derivative helps in creating security market more efficient and provides liquidity to the market, which encourage investors to make investment in share market. The transfer of risk enables market participants to expand their volume of activity.

\section{Types Of Financial Derivative}

There are various types of financial derivatives which are available in the security market for trading as per the need of investor. Basically there are two types of derivatives, out of which one is financial derivative and another is commodity derivative. It is the nature of underlying asset on which basis the classification of derivatives based. The most commonly used derivatives contracts are forwards, futures and options.

\subsection{Forward Contracts}

A forward contract is a customized contract between two parties, where one party agrees to sell and another party agrees to purchase a specific assets, at a specified price and for a specified period of time and the settlement takes place in future on a specific date in the future at today's pre-agreed price. These contracts are traded through over-the-counter market not by stock exchange traded and are non-standardized contracts, as not traded through stock exchanges.

\subsection{Futures Contracts}

Suppose a farmer produces rice and he expects to have an excellent yield on rice; but he is worried about the future price fall of that commodity. How can he protect himself from falling price of rice in future? $\mathrm{He}$ may enter into a contract on today with some party who wants to buy rice at a specified future date on a price determined today itself. In the whole process the farmer will deliver rice to the party and receive the agreed price and the other party will take delivery of rice and pay to the farmer. In this illustration, there is no exchange of money and the contract is binding on both the parties. Hence future contracts are forward contracts traded only on organized exchanges and are in standardized contract-size. The farmer has protected himself against the risk by selling rice futures and this action is called short hedge while on the other hand, the other party also protects against-risk by buying rice futures is called long hedge.

\subsection{Option Contracts}

As the name indicates option means the buyer have the option to execute the contract or not to execute the contract but seller have no such type of option, they have to execute the contract. This is also a specified contract between two parties for a specified period at a specified price and for a specified period. Versatility is the main importance of option contracts. Option is a financial instrument with the advantage of only upside without downside, as the maximum loss is only up to the premium amount on the situation of out of the money and at-the money options. Out of the money is a condition when strike price is more than current price in case of call option and reverse in put option. There are various strategies which help in gaining the popularity of option contract. Option strategy like protective put, covered call, straddle etc., helping to protect the investor portfolio against the fall in its price. All the option strategies are helps in controlling the overall portfolio risk.

Hedging and speculation are important tools to control over price fluctuation. Hedging is a tool to control losses by taking simultaneously opposite position, with a holding position. To protect against the loss of falling market one can take put option or short call option, which helps in controlling over the future risk. NSE had launched trading in option on individual securities from July 2, 2001, for the first time in India. The following table elaborates the chronological development of financial derivatives in Indian Security Market. 
Table 1

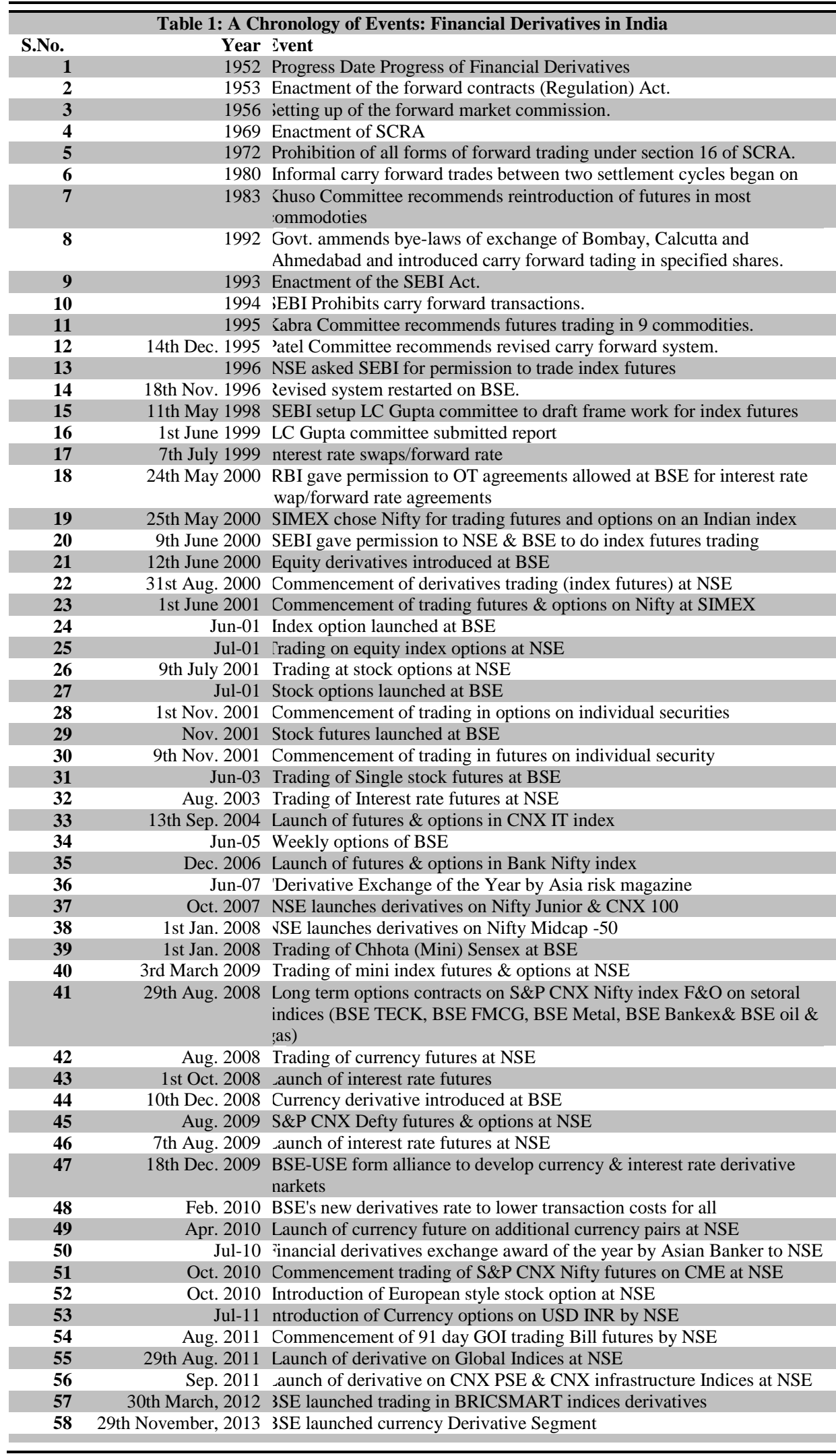

Source: Compiled from NSE \& BSE website 
Table 2 : Business Growth in FO Segment

\begin{tabular}{|c|c|c|c|c|c|c|c|c|c|}
\hline \multirow[t]{2}{*}{ Year } & \multicolumn{2}{|c|}{ Index Futures } & \multicolumn{2}{|c|}{ Stock Futures } & \multicolumn{2}{|c|}{ Index Options } & \multicolumn{2}{|c|}{ Stock Options } & $\begin{array}{c}\text { Average } \\
\text { Daily } \\
\text { Turnover }\end{array}$ \\
\hline & $\begin{array}{l}\text { No. of } \\
\text { contracts }\end{array}$ & $\begin{array}{l}\text { Turnover } \\
\text { (Rs. Cr.) }\end{array}$ & $\begin{array}{l}\text { No. of } \\
\text { contracts }\end{array}$ & $\begin{array}{l}\text { Turnover } \\
\text { (Rs. Cr.) } \\
\end{array}$ & $\begin{array}{l}\text { No. of } \\
\text { contracts }\end{array}$ & $\begin{array}{l}\text { Notional } \\
\text { Turnover } \\
\text { (Rs. Cr.) } \\
\end{array}$ & $\begin{array}{l}\text { No. of } \\
\text { contracts }\end{array}$ & $\begin{array}{l}\text { Notional } \\
\text { Turnover } \\
\text { (Rs. Cr.) } \\
\end{array}$ & (Rs. Cr.) \\
\hline 2014-15 & 21866521 & 781940.72 & 48415080 & 1789643.7 & 158734718 & 5696734 & 17604910 & 666655.4 & 175195.6 \\
\hline 2013-14 & 105270529 & 3085296.5 & 170414186 & 4949281.7 & 928565175 & 27767341 & 80174431 & 2409489 & 152236.7 \\
\hline 2012-13 & 96100385 & 2527130.8 & 147711691 & 4223872 & 820877149 & 22781574 & 66778193 & 2000427 & 126638.6 \\
\hline 2011-12 & 146188740 & 3577998.4 & 158344617 & 4074670.7 & 864017736 & 22720032 & 36494371 & 977031.1 & 125902.5 \\
\hline 2010-11 & 165023653 & 4356754.5 & 186041459 & 5495756.7 & 650638557 & 18365366 & 32508393 & 1030344 & 115150.5 \\
\hline 2009-10 & 178306889 & 3934388.7 & 145591240 & 5195246.6 & 341379523 & 8027964 & 14016270 & 506065.2 & 72392.07 \\
\hline 2008-09 & 210428103 & 3570111.4 & 221577980 & 3479642.1 & 212088444 & 3731502 & 13295970 & 229226.8 & 45310.63 \\
\hline $2007-08$ & 156598579 & 3820667.3 & 203587952 & 7548563.2 & 55366038 & 1362111 & 9460631 & 359136.6 & 52153.3 \\
\hline 2006-07 & 81487424 & 2539574 & 104955401 & 3830967 & 25157438 & 791906 & 5283310 & 193795 & 29543 \\
\hline $2005-06$ & 537886 & 1513755 & 80905493 & 2791697 & 12935116 & 338469 & 5240776 & 180253 & 19220 \\
\hline 2004-05 & 635449 & 772147 & 47043066 & 1484 & 3293558 & 121943 & 5045112 & 3836 & 10107 \\
\hline 2003-04 & 91668 & 554446 & 32368842 & 1305939 & 1732414 & 52816 & 5583071 & 217207 & 8388 \\
\hline $2002-03$ & 6763 & 43952 & 10676843 & 286533 & 442241 & 9246 & 3523062 & 100131 & 1752 \\
\hline 2001-02 & 1025588 & 21483 & 1957856 & 51515 & 175900 & 3765 & 1037529 & 25163 & 410 \\
\hline $2000-01$ & 90580 & 2365 & & & & & & & 11 \\
\hline
\end{tabular}

http://www.nseindia.com/content/fo/fo_businessgrowth.htm

On the basis of above table the \% change in turnover has been found out as mentioned below. Table 3 explained that all derivative contracts have decreased in the turnover during the period 2008-09 and 2012-13 except one that is Index option, this was because of global financial crisis. The index future turnover has further reduced during $2012-13$ by $29.37 \%$, but others were recovered.

Table 3

\begin{tabular}{|l|r|r|r|r|}
\hline Year & $\begin{array}{l}\text { \% Change in } \\
\text { Turnover }\end{array}$ & $\begin{array}{l}\text { \% Change in } \\
\text { Turnover }\end{array}$ & $\begin{array}{l}\text { \% Change in } \\
\text { Turnover }\end{array}$ & $\begin{array}{l}\text { \% Change in } \\
\text { Turnover }\end{array}$ \\
\hline & Index Future & Stock Future & Index Option & \multicolumn{1}{c|}{ Stock Option } \\
\hline$\underline{2000-01}$ & & & & \\
\hline$\underline{2001-02}$ & 808.3721 & & & 297.9295 \\
\hline$\underline{2002-03}$ & 104.5897 & 456.21275 & 145.57769 & 116.92283 \\
\hline$\underline{2003-04}$ & 1161.481 & 355.77263 & 471.2308 & -22.26954 \\
\hline$\underline{2004-05}$ & 39.2646 & 13.638998 & 130.88269 & 6.7621834 \\
\hline$\underline{2005-06}$ & 96.04492 & 88.112645 & 177.56329 & 7.5127737 \\
\hline$\underline{2006-07}$ & 67.76651 & 37.227178 & 133.96707 & 85.317784 \\
\hline$\underline{2007-08}$ & 50.4452 & 97.040674 & 72.004127 & -36.17281 \\
\hline$\underline{2008-09}$ & -6.55791 & -53.903253 & 173.94992 & 120.77052 \\
\hline$\underline{2009-10}$ & 10.20353 & 49.304051 & 115.14028 & 103.59906 \\
\hline$\underline{2010-11}$ & 10.73523 & 5.7843279 & 128.76742 & -5.1742816 \\
\hline$\underline{2011-12}$ & -17.8747 & -25.857877 & 23.711294 & 104.74548 \\
\hline$\underline{2012-13}$ & -29.3703 & 3.6616775 & 0.2708711 & 20.448734 \\
\hline$\underline{2013-14}$ & 22.08693 & 17.174046 & 21.885086 & \\
\hline
\end{tabular}

Strategy is a plan for achieving the predetermined goal and the main purpose of the futures market is to minimizing the risk in the existing stock market. Due to the uncertainty in share price, there is needed to take hedging position. Hedging is a strategy of minimizing the risk against the already holding position in the stock market. Long and short hedging facilities are available in future contracts.

Every investor would like to manage risk as the investment is for future period and future is always uncertain. By taking financial derivative instruments like Index Futures \& Options, Stock Futures \& Options etc., investors can reduce the risk of uncertainty. These instruments help investors in creating an effective portfolio.

By Jauanath Verma "It is this liquidity that makes derivatives attractive to the rogue traders. Doubling strategies can be adopted only in very liquid markets and derivatives tend to the bill excellently. Second, derivatives provide enormous amount of leverage. It is possible to take large derivative position with relatively small initial investment."

Derivative have both good and bad characters, it depends on the portfolio manager how to use derivative products and gets maximum benefits.

As per the ISDA organization research, in 2009 ISDA Derivatives Usage Survey, reports that $94 \%$ of the world's largest using derivatives to manage business and macroeconomic risks and currency derivatives and interest rate derivatives are mostly used by developed companies economies. RBI states that there should be a 
prudent system to control the risk involved in derivatives. Top level management should have appropriate oversight and adequate risk management process that integrates prudent risk limits, sound measurement procedures and information systems, continuous risk monitoring and frequent management reporting; and comprehensive internal controls and audit procedures.

For the development of an economy financial sectors play a major role. After the economic reform 1991 i.e. privatization and globalization, facilitate industrial revolution and restructuring, which required more capital and new instruments of investment. Investment is related with risk, and that risk can be minimized with the help of derivative instruments. Most of the financial institution are using financial derivative as a risk management tool and providing lower cost of financial services to their customers. Derivative contracts are also involved certain types of risk like market risk, operational risk credit risk, liquidity risk, and legal risk etc. Out of these risks credit risk and market risk directly related with the market price movements. Market risk is the inverse change in the stock price. Due to the variability in the stock price there is required to identify and measuring the risk and find out the most suitable method to mitigate that risk. Financial derivatives are available to control over such types of risk with hedging strategy. Credit risk is related with default in making payment, which can be control by mark-to-market process in future market, and with proper internal control system. Various regulatory framework are also available to control over risk like notional or volume limit, stop loss limit, gap or maturity band limit.

In the words of R. H. Patil, "Despite the obvious risks that individual stock futures pose to the safety and integrity of the capital market of the country, they have been introduced in a hurry in our country. In my opinion it was not a wise thing for us to have introduced individual stock futures. All those who had mourned the death of badla are very happy that a similar product is now available for them to play their games", which means all were not in favour of launching individual stock future. There is a question arise whether the introduction of derivative products helps in controlling over the risk(volatility) in the share market actually or they are only fake."

Derivative contracts don't have their own value or they are not independent, as the value is derived form an underlying asset. But the risk involved in the investment of an underlying asset can be hedge with the derivative instruments. The using of derivative instruments can be good luck for those who executed properly as of liquidity and relatively lower cost, but bad luck for those who are unaware and not executed properly because of their complex properties.

\section{Uses Of Financial Derivative}

Generally derivatives are used as risk management tools. Here is the brief description of their uses.

Risk aversion tools: One of the most important services provided by the derivatives is to transfer and manage the risk in an efficient manner with the help of various strategies of option and future contracts. To manage highly volatile financial market derivative contracts worked as a risk minimizing tool by taking hedging, speculating and arbitraging position in the market.

Prediction of future prices: Investors are always would like to predict about the future share price, so that they can make investment at right time and get maximum return. Derivatives works as barometers to predict the price of future share market as well as spot market. They also help in collecting and spreading different information regarding the futures markets trading of various commodities and securities. These help the society to discover true symmetry prices in the markets.

Enhance liquidity: Derivatives are based on margin trading system where only certain percentage of total amount of contract is required to pay as margin. Due to the margin trading system investors, speculators, hedgers etc. are interested to take position in derivative market, which boost liquidity and diminish trans-action costs in the markets for underlying assets.

Assist investors: The derivatives assist the investors, traders and managers of large pools of funds to devise such strategies so that they may make proper asset allocation increase their yields and achieve other investment goals.

Integration of price structure: It has been witnessed from the derivatives trading in the market that the derivatives have control over price fluctuations, cuddle the price spread, integrate price structure at different points of time and remove excesses and shortages in the markets.

Enhancing growth of financial markets: The growth of financial market depends on the effective trading instruments, which encourage the competitive trading in the markets. Various operators are interested in doing trading in share market because it facilitate to hedge or speculate the risk by using derivative instruments. Derivative instruments attract young investors, experts and other connoisseurs who will helps in the growth of financial markets.

Brings faultlessness in market: Investors are interested in getting faultless return on their investment. Faultless return means controlled return, and controlled return refers that return which is better off than others, which they can get by taking various strategies of future and option contracts. 


\section{Factors Motivating The Expansion Of Financial Derivatives In India}

- Increased fluctuations in security prices in financial market and to control such fluctuations trading in derivatives are increased.

- Globalization of Indian economy and integration with international financial market motivate investors to make investment in Derivative markets.

- Improvement in security trading techniques and effective information and communication system helps in increasing the trading volume of Derivatives.

- Electronic trading system helps in decline the cost of derivative trading, which helps in generating revenue to security market

- Various risk management tools, professional or expertise services helps in controlling and managing risk in security market trading, which is good for derivative trading.

- Requirement of margin amount only is also an important factor behind the increasing trading volume of financial derivatives.

\section{Global Derivative Market}

The growth of derivatives all over the world during the year 2013 can be estimated by following statistical data: 9.1 Global Futures and Options Volume

Based on the number of contracts traded and/or cleared at 84 exchanges worldwide:

Table: 4

\begin{tabular}{llll}
\hline & Jan-Dec 2012 & Jan-Dec 2013 & \% Change \\
\hline Future & $11,072,105,368$ & $12,217,755,153$ & $10.3 \%$ \\
Option & $10,118,012,082$ & $9,425,664,621$ & $-6.8 \%$ \\
Total & $21,190,117,450$ & $21,643,419,774$ & $2.1 \%$ \\
\hline
\end{tabular}

Source: http://www.futuresindustry.org/downloads/FIA_Annual_Volume_Survey_2013.pdf

The entire data in above tables is based on the number of contracts traded \&/ or cleared at 84 stock exchanges worldwide.

Table 4 discloses data concerning the global futures and options volume. The global futures and options volumetable disclose the fact that globally, futures contracts trading volume exceeds that of options contracts trading volume in year 2013 but in India, as is revealed from Table trading volume of F\&O segment, the trading volume of option index is more than the future index. Globally future volume has increased by $10.3 \%$ but option volume has negatively increased by $-6.8 \%$. The overall increase in total derivative segment is $2.1 \%$ from the year 2012 to 2013 .

9.2 Global Futures and Options Volume by Category

Based on the number of contracts traded and/or cleared at 84 exchanges worldwide:

Table 5

\begin{tabular}{llll}
\hline Categories & Jan-Dec 2012 & Jan-Dec 2013 & \% Change \\
\hline Individual Equity & $6,469,512,853$ & $6,401,526,238$ & $-1.1 \%$ \\
Equity Index & $6,048,270,302$ & $5,370,863,386$ & $-11.2 \%$ \\
Interest Rate & $2,931,840,769$ & $3,330,719,902$ & $13.6 \%$ \\
Currency & $2,434,253,088$ & $2,491,136,321$ & $2.3 \%$ \\
Energy & $925,590,232$ & $1,265,568,992$ & $36.7 \%$ \\
Agriculture & $1,254,415,510$ & $1,213,244,969$ & $-3.3 \%$ \\
Non-Precious Metals & $554,249,054$ & $646,318,570$ & $16.6 \%$ \\
Other & $252,686,977$ & $493,359,639$ & $95.2 \%$ \\
Precious Metals & $319,298,665$ & $430,681,757$ & $34.9 \%$ \\
\hline Total & $21,190,117,450$ & $21,643,419,774$ & $2.1 \%$ \\
\hline
\end{tabular}

Note: Other includes contracts based on commodity indices, credit fertilizer, housing, inflation, lumber, plastics and weather.

Table 5 discloses data concerning the global futures and options volume by category wise for the period 2012 an 2013. There has positively increased in the trading volume of derivatives for the categories like interest rate, currency, energy, non-precious metals, precious metals, and others. But for individual equity, equity index and for agriculture the trading volume has decline during 2013 in comparison to 2012. 


\subsection{Top 10 Derivative Exchanges in the world during the year 2013:}

Table 6 Ranked by number of contracts traded and/or cleared

\begin{tabular}{llll}
\hline Rank & Exchange & Jan-Dec 2013 Volume & Annual \% Change \\
\hline $\mathbf{1}$ & CME Group & $3,161,476,638$ & 9.2 \\
$\mathbf{2}$ & Intercontinental Exchange & $2,807,970,132$ & 14.7 \\
$\mathbf{3}$ & Eurex & $2,190,548,148$ & -4.4 \\
$\mathbf{4}$ & National Stock Exchange of India & $2,135,637,457$ & 6.2 \\
$\mathbf{5}$ & BM\&F Bovespa & $1,603,600,651$ & -2.0 \\
$\mathbf{6}$ & CBOE Holdings & $1,187,642,669$ & 4.7 \\
$\mathbf{7}$ & Nasdaq OMX & $1,142,955,206$ & 2.5 \\
$\mathbf{8}$ & Moscow Exchange & $1,134,477,258$ & 6.8 \\
$\mathbf{9}$ & Korea Exchange & $820,664,621$ & -55.3 \\
$\mathbf{1 0}$ & Multi Commodity Exchange of India & $794,001,650$ & -17.3 \\
\hline
\end{tabular}

http://www.futuresindustry.org/downloads/FIA_Annual_Volume_Survey_2013.pdf

The above table explained various stock exchanges related to their trading volume during the year 2013 and ranked them accordingly. India's National Stock Exchange is one of top ten exchanges of the world in terms of number of contracts traded. It ranks as fourth largest exchange in terms of number of contracts traded; CME Group is on the top among all the Exchange. NSE has moved up the in the ranking in 2013 as it was on fifth rank in the world during 2012, 2011 and 2010 in derivative trading.

\section{Conclusion}

Indian financial derivative market has a great place for investment as it has modern techniques and innovative products for investment. These instruments are also safe to make investment as they are traded through esteemed stock exchanges like BSE and NSE in India. During the year 2008 Indian financial market faced financial crisis but with the help of various innovative and new investment instruments market abled to create its possession in the world financial market. Derivatives are also known as risk management instruments but still they required a proper regulatory framework, which helps to regulate the financial derivatives regarding major issues like investor protection by providing fairness and transparency in trading system and market integrity. Regulatory authorities like SEBI should have provide quality market, which are cost efficient, stability of price and helps in discovering price.

\section{Journal Papers:}

\section{References}

[1]. R. H. Patil, "Current state of the Indian Capital Market". Economic \& Political Weekly, 18 March 2006, Vol - XLI No. 11, Banking $\&$ Finance.

[2]. Peter Koslowski, The Ethics of Banking: Conclusions from the Financial Crisis, pg. 85, Springer Science \& Business Media, 20Apr-2011 - Business \& Economics.

[3]. Fact Book, June 2012, India The Incredible Investment Destination, Department of Economics Affairs, Ministry of Finance, Government of India.

Books:

[4]. John C.Hull, 2009, Option, futures, and other derivatives, Seventh Edition Pearson Prentice Hall, Pg. 40.

[5]. Jayanath Rama Verma, 2008, , Derivatives and Risk Management, Tata Mcgraw Hill, p.1.9).

\section{Online Link:}

[6]. http://www.isda.org/researchnotes/pdf/ISDA-Research Notes2.pdfhttp://www.rbi.org.in/Scripts/bs viewcontent.aspx?ld=457

[7]. http://www.usnews.com/opinion/blogs/economic-intelligence/2012/07/16/derivatives should-be-banned-from-financial-markets, July 16, 2012 ,

[8]. http://www.futuresindustry.org/downloads/FIA_Annual_Volume_Survey_2013.pdf

[9]. file:///C:/Users/Admin17/Downloads/India_Factbook.pdf

[10]. http://www.world-exchanges.org/statistics/monthly-reports, Report of World Federation of Exchange.

[11]. Future and Option World (FOW), http://www.fow.com/ 